\title{
Brake torque analysis of fully mechanical parking brake system: Theoretical and experimental approach
}

\section{Análisis de par de frenado del sistema de freno de estacionamiento mecánico: enfoque teórico y experimental}

\author{
Mohd-Razmi Ishak \\ Universiti Teknologi Malaysia \\ Faculty of Mechanical Engineering \\ E-mail: razmi_ishak@yahoo.com \\ Abd-Rahim Abu Bakar \\ Universiti Teknologi Malaysia \\ Faculty of Mechanical Engineering \\ E-mail: arahim@fkm.utm.my
}

Ali Belhocine

University of Sciences and the Technology of Oran, USTO, Algeria

Faculty of Mechanical Engineering

E-mail: al.belhocine@yahoo.fr

\author{
Jamaludin-Mohd Taib \\ Universiti Teknologi Malaysia \\ Faculty of Mechanical Engineering \\ E-mail: jamalt@fkm.utm.my \\ Wan-Zaidi Wan Omar \\ Universiti Teknologi Malaysia \\ Faculty of Mechanical Engineering \\ E-mail:wanzaidi@fkm.utm.my
}

\begin{abstract}
The effect of the reduction of drum brake temperature on the clamping force of the parking brake system has not been well addressed despite the fact that it may result in vehicle roll away. In view of this, parking brake model that takes into account the temperature reduction of the drum brake has to be developed and more importantly, it must comply with the applicable standards or regulations such as FMVSS 135. This paper develops a one dimensional (1D) model of leading-trailing drum-type parking brake model. This brake model is then verified with experiments carried out on a test bench that has been calibrated with the hand brake system in the vehicle. The results from the experiments show a good correlation with the predicted results from the brake model. With the verified brake model, parametric studies can be carried out as one of the tools during the design process.
\end{abstract}

Keywords: parking brake model, torque, drum brake, temperature, roll away.

\section{Resumen}

El efecto de la reducción de la temperatura de los frenos de tambor en la fuerza de sujeción del sistema de freno de estacionamiento no se ha estudiado correctamente a pesar del hecho de que puede resultar en el vuelco del vehículo. En vista de esto, el modelo de freno de estacionamiento que tiene en cuenta la reducción de la temperatura del freno de tambor tiene que desarrollarse y, lo más importante, debe cumplir con las normas o reglamentos aplicables, como FMVSS 135. En este trabajo se desarrolla un modelo unidimensional del modelo de freno de estacionamiento tipo tambor. Este modelo de freno se verifica con los experimentos realizados en un banco de pruebas que se calibraron con el sistema de freno de mano en el vehículo. Los resultados de los experimentos muestran una buena correlación con los resultados predichos a partir del modelo de freno. Con el modelo de freno verificado, estudios paramétricos pueden llevarse a cabo como una de las herramientas durante el proceso de diseño.

Descriptores: modelo de freno de estacionamiento, el par, frenos de tambor, temperatura, extraíble. 


\section{INTRODUCTION}

The car following situations had been studied over the years because of its importance in understanding and predicting human behavior to accelerate and brake (Carrillo et al., 2015). Brakes are one of the most important safety systems in a motor vehicle. The main functions are to decelerate, to maintain the speed during downhill operation, and finally to park the vehicle stationary either a flat or sloped road condition. The first two functions are related to the service brakes, while the last function is referred to the secondary or parking brakes (Limpert, 1999). The basic principle of the brake system is to provide the clamping force between the disc/pad and drum/lining. Insufficient clamping force may cause the vehicle to fail to decelerate or stop as intended. This may cause danger to the vehicle, driver, passengers, pedestrians and other road users. In ground vehicles, mechanical parking brake is a mechanism to hold the vehicle stationary either a flat or sloped road. It consists of a cable that is directly connected to the brake unit on one end and to an actuating lever on the other end. Several mechanical configurations have been tested via computer simulation (Bortoni et al., 2013). This actuating mechanism is often a handoperated lever or a pull handle, or a foot-operated pedal (Limpert, 1999). The European Economic Community (EEC) regulation (U.N. Inland Transport Division, 2008) specified that the handbrake system of a laden vehicle in class M1 (passenger cars comprising no more than eight seats in addition to the driver's seat) must be able to hold the vehicle in $20 \%$ gradient. Thiessen (1987) suggested that the parking brake is designed to hold a vehicle stationary over any desired time period. In addition, the parking brake should be able to hold a vehicle stationary for $30 \%$ gradient with a maximum applied force on the parking brake pedal of $445 \mathrm{~N}$ for a vehicle with the hand-operated parking brake lever. Federal Motor Vehicle Safety Standard (FMVSS) 135 (U.S. National Highway, 2005) specified that, for standard passenger vehicles with weight of $3500 \mathrm{~kg}$ and below, the vehicle should be able to stay stationary on $20 \%$ grade road for 5 minutes in both forward and reverse directions, with $400 \mathrm{~N}$ or less force applied at the hand control of the parking brake mechanism. To date, a lot of literatures have discussed the braking performance of the service brakes (Limpert, 1999, Xiaoyan et al., 2012; Tirovic et al., 2011; Hwang et al., 2009; Koylu and Cinar, 2012; Zhang et al., 2012; Belhocine and Bouchetara, 2012; Tao and Chang, 2003; Aleksendric and Barton, 2009; Bao et al., 2012; Mutlu et al., 2005), but only a handful have been done on the parking brakes. For in- stance (McKinlay et al., 2003; McKinlay et al., 2006); investigated conventional parking brake performance in term of vehicle roll away for the disc brakes through laboratory tests and theoretical approaches. In the theoretical approach, one-dimensional (1-D) lumped parameter model of disc-type parking brake system using simple linear spring element had been proposed to predict the clamping force. A laboratory parking brake test rig was then developed to measure the clamping force of the parking brake system, which is used to validate the results from the 1-D model. In their study, they had been considered the thermal effects on the braking torque and vehicle roll away. Recently, Rozaini et al. (2013) investigated fully mechanical parking brake system in terms of torque performance using combined analytical-experimental approach without considering thermal effects. They developed one dimensional rigid parking brake model and validated the model by comparing brake torque versus hand-brake lever force over measured data. To the authors' knowledge, there is no information available in the public domain to investigate the torque performance of a drum-type parking brake system with thermal effect. Thus, the current work attempts to establish a theoretical model of the drum parking brake and validate the results against test results measured from the parking brake test bench.

\section{Parking brake tests}

In this work parking brake test bench (Rozaini et al., 2013) for a typical full mechanical hand lever operated, drum-type parking brake system as shown in Figure 1 was used. The test bench consists of a set of parking brake mechanism connected to a pair of rear-drum brake unit, two hydraulic pumps, an actuator, a flywheel, a $5.5 \mathrm{~kW}$ DC motor with speed controller, and

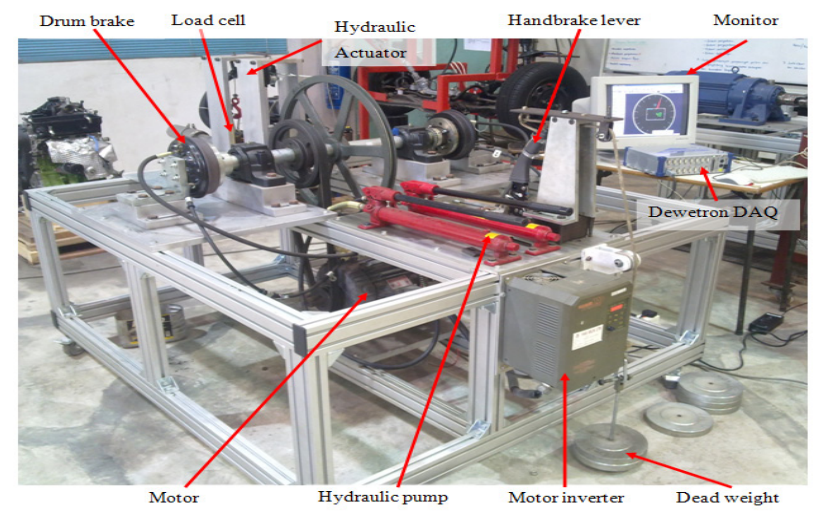

Figure 1. Parking brake test bench (Rozaini et al., 2013) 
one load cell. One of the hydraulic pumps is used to supply brake pressure to the drum brake to simulate the brake in normal operations, which heat up the brake unit, whilst the other one is connected to the actuator, which is used to pull a cable that connects to the flywheel and the load cell. This will measure brake torque produced by the drum brake unit when the hand lever is being pulled (McKinlay et al., 2004). To engage the parking brake, force on the hand lever is applied using deadweight that is connected to the hand lever using cable and pulley. The DC motor rotates the drum brake and as the drum rotates, the friction force will create heat and will increase it over a time period.

After the test bench is being developed, verification and calibration process is carried out by comparing the force of the load cell with the applied force to lift the hand lever of an actual car. Having been satisfied with the calibration process, the test bench was ready to be used. In this work, the test was conducted by heating up the drum brake for different hand-brake applied forces until it reached the maximum temperature of $250^{\circ} \mathrm{C}$. Standard initial temperature to test the effect vehicle roll away phenomenon stated by McKinlay et al. (2004) is $300^{\circ} \mathrm{C}$. However, using the available motor, that temperature level is difficult to be achieved. This is because, during the dragging process, drum and lining temperature will increase drastically so as the coefficient of friction at lining's/drum's interface. When the friction coefficient is too high, the torque produced by the drum brake is much higher than the torque of the DC motor. This causes the DC motor to stop. Due to this problem, dragging process can only be executed until the drum surface temperature achieves around $250^{\circ} \mathrm{C}$. After the dragging process, delay time is allocated to set up the cable actuator to drive wheel so that external torque could be applied to drive shaft after the rear drum unit heated. The delay time causes the drum temperature drops. Therefore, this test is run with the initial temperature at $200^{\circ} \mathrm{C}$. The temperature of the outer surface of the drum is measured using a non-contact temperature sensor (Brand: Cole-Parmer N-08406-00). Since the outer surface of the drum is exposed to the ambient air, it is expected that the drum will be cooled down much faster than the shoes and hence, the drum will be shrinking early than the shoes. Then, the parking brake torque was measured five minute intervals (Day et al., 1984) up to one hour.

\section{CoOling model}

Temperature change $\Delta T$ is the increment of drum temperature $T_{t}$ at the specific time $t$ in relation to its initial temperature, too, which is the temperature when the hand-brake lever was initially applied. Thus, the temperature change will be

$\Delta T=T_{t}-T_{o}$

With the assumption of convection is dominant in the cooling process (Wolff, 2010), the temperature at certain times $T_{t}$ is

$T_{t}=\left(T_{o}-T_{a m b}\right) e^{-\left[\frac{h A t}{p c_{p} V}\right]}+T_{a m b}$

where

$T_{\text {amb }} \quad=$ ambient temperature

$h=$ the heat transfer coefficient

$A \quad=$ the surface area where heat being transferred

$\rho \quad=$ the density of the drum

$c_{p} \quad=$ drum specific heat capacity per unit mass

$V \quad=$ volume of the drum

\section{ANALYSIS OF BRAKE TORQUE}

In the parking brake analysis, two models are used, i.e. parking brake model and on-slope vehicle model. The first model is employed to calculate brake torque produced by the parking brake system whilst the vehicle model is used to determine torque that needs to hold the vehicle stationary. The vehicle is said to be rolled away if the torque from the vehicle model exceeds the torque from the parking brake model.

\section{PARKING BRAKE MODEL}

Figure 2 shows the arrangement of a parking brake system used in this work. This arrangement is schematically represented as one dimensional model using linear spring as shown in Figure 3. The model is based on McKinlay model (McKinlay et al. 2004) and it has been modified to suit this study. The derivation of the parking brake torque starts from hand-brake lever and it is transmitted through the brake cable. Engagement of the hand-brake lever cause tension $F_{c}$ in the cable (Figure 4), which always depend on the force applied $F_{h b}$ to the lever and the hand lever arm length, $l_{a}$. This is reacted by the force in the cable and the cable lever arm length, $l_{b}$. Figure 4 illustrates the forces on the handbrake lever, the length of hand lever arms, $l_{a}$ and the length of the cable lever arm, $l_{b}$. 

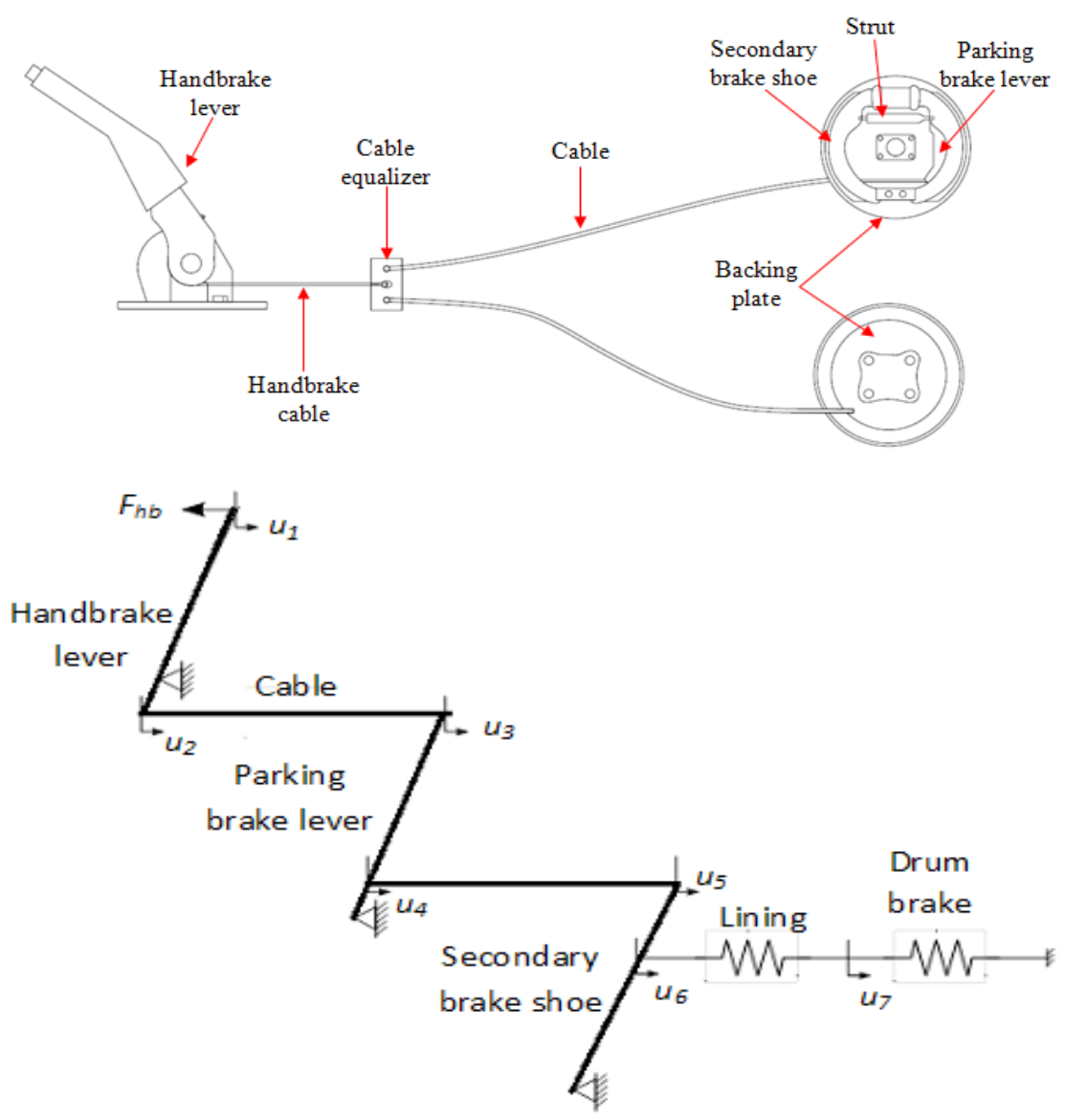

Figure. 2. Typical parking brake system

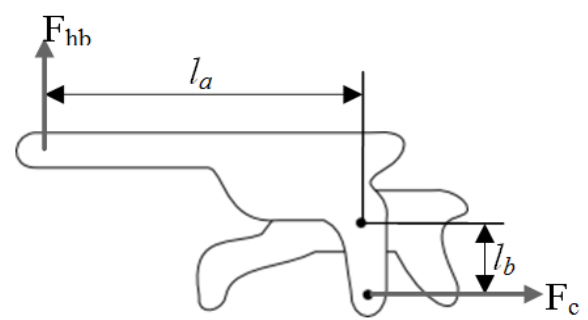

Figure. 4. Forces at hand-brake lever ( $\mathrm{A}$ is the pivot point and $\mathrm{B}$ is the cable attachment point)

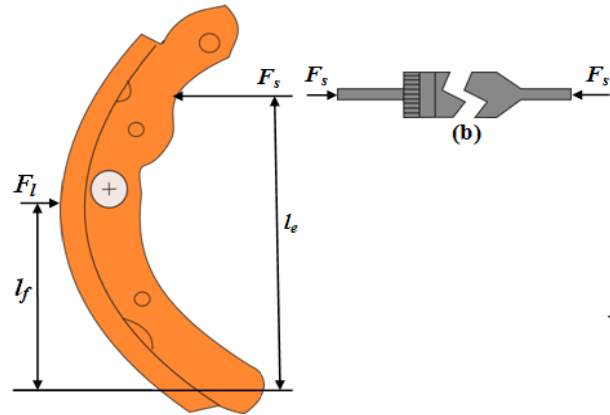

(a)

Figure. 5. Forces at a) secondary brake shoe, b) strut, and c) parking brake lever
Then from Figure 5, ratio of reaction forces at the brake shoe is

$$
\frac{F_{s}}{F_{l}}=\frac{l_{f}}{l_{e}}=\frac{u_{6}}{u_{5}}
$$

When the brake shoe pushes the drum brake, the deformation of the lining $\left(u_{6}\right)$ and the drum $\left(u_{7}\right)$ will be occurred. This deformation can be used to find the relationship between the force and the deformation of the lining and the drum. The force of deformable component is generally given by

$F_{c}=\frac{A_{c} E_{c} \delta_{c}}{l_{c}}$ 
where

$F_{c}(\mathrm{~N}) \quad=$ cable load

$A_{c}\left(\mathrm{~m}^{2}\right)=$ cross sectional area

$E_{c}\left(\mathrm{Nm}^{-2}\right)=$ modulus of elasticity

$\delta_{c}(\mathrm{~m})=$ linear deformation and

$l_{c}(\mathrm{~m}) \quad=$ is the initial thickness of the component

When the reaction force between the brake lining and drum brake interface is equal and the deformation of both parts formed due to force reaction and thermal effect, the force between the interfaces will be derived as

$\sum F_{d}=\sum F_{l}$

where $\sum F_{d}$ is described as the summation force reaction on the drum surface and $\sum F_{l}$ is described as the summation force reaction on the lining surface.

When the radial load $F_{\delta_{l}}$ and thermal load $F_{\delta_{T}}$ are taken into account, Eq. (5) will transform into Eq. (6) as shown below

$\sum\left(F \sum\left(\delta_{l}+\delta_{d}\right)+F \sum \delta_{T}\right)_{d}=\sum\left(F \sum \delta_{l}+F \sum \delta_{T}\right)_{l}$

By substituting $F$ from Eq. (4) into Eq. (6), the equation will expand to

$\left[\frac{A_{l} E_{l}}{l_{o l}}+\frac{A_{d} E_{d}}{l_{o d}}\right] \delta_{l, d}+\left[\frac{A_{d} E_{d}}{l_{o d}}\right] \delta_{T, d}=\left[\frac{A_{l} E_{l}}{l_{o l}}\right] \delta_{l, l}+\left[\frac{A_{l} E_{l}}{l_{o l}}\right] \delta_{T, l}$

where

$\delta_{l, d}$ and $\delta_{T, d}=$ drum displacement due to radial load and thermal reactions respectively

$\delta_{l, l}$ and $\delta_{T, l}=$ displacements of lining due to radial and thermal loads, respectively

As illustrated in Figure 3, the radial deformation against the lining is $u_{6}$ and the radial deformation at the drum/ lining interface is $u_{7}$. Assuming that the drum and lining are homogeneous, the deformations of both components in relation to the thermal change $\delta T$ is proportional to both the temperature change and the thickness of the component. Hence

$\delta_{T}=\alpha(\Delta T) l$

where $\alpha$ is a constant characteristic of the material, called the coefficient of thermal expansion.

Temperature change $\Delta T$ is the increment of drum temperature $T_{t}$ at the specific time $t$ in relation to its initial temperature, too, which is the temperature when the hand-brake lever was initially applied. Thus, the temperature change will be

$$
\Delta T=T_{t}-T_{o}
$$

With the assumption of convection is dominant in the cooling process (Wolff, 2010), the temperature at certain times $T_{t}$ is

$T_{t}=\left(T_{o}-T_{a m b}\right) e^{-\left[\frac{h A t}{p c_{p} V}\right]}+T_{a m b}$

where

$T_{a m b}=$ ambient temperature

$h \quad=$ heat transfer coefficient

$A \quad=$ surface area where heat being transferred

$\rho \quad=$ density of the drum

$c_{p} \quad=$ drum specific heat capacity per unit mass

$V \quad$ = volume of the drum

After all the deformations in Eq. (7) are substituted, the equation becomes

$u_{7}\left[\frac{A_{l} E_{l}}{l_{o l}}+\frac{A_{d} E_{d}}{l_{o d}}\right]+\frac{A_{d} E_{d}}{l_{o d}}\left(\alpha_{d} \Delta T l_{o d}\right)=u_{6}\left[\frac{A_{l} E_{l}}{l_{o l}}\right]+\frac{A_{l} E_{l}}{l_{o l}}\left(\alpha_{l} \Delta T l_{o l}\right)$

To cancel out the denominators in Eq. (11), $l_{o l} l_{\text {od }}$ is multiplied to the equation. A new force equation is formed as follows

$u_{7}\left(A_{l} E_{l} l_{o d}+A_{d} E_{d} l_{o l}\right)+A_{d} E_{d}\left(\alpha_{d} \Delta T l_{o l} l_{o d}\right)=u_{6} A_{l} E_{l} l_{o d}+A_{l} E_{l}\left(\alpha_{l} \Delta T l_{o l} l_{o d}\right)$

By rearranging Eq. (12) to solve for $u_{7}$ which is the displacement between brake shoe/drum brake interfaces, can be represented by

$u_{7}=\frac{u_{6} A_{l} E_{l} l_{o d}+A_{l} E_{l}\left(\alpha_{l} \Delta T l_{o l} l_{o d}\right)-A_{d} E_{d}\left(\alpha_{d} \Delta T l_{o l} l_{o d}\right)}{\left(A_{l} E_{l} l_{o d}+A_{d} E_{d} l_{o l}\right)}$

With equation of deformation, the radial force at the frictional interface is represented by

$F_{l}=\frac{A E \delta}{l}=\frac{A E}{l} \sum \delta=\frac{A E}{l} \sum\left(\delta_{T}+\delta_{s}\right)=\frac{A E}{l} \sum\left(\delta_{T}+u_{7}\right)$

By replacing the thermal deformation and force deformation into the equation, the force at the interface becomes 
$F_{l}=\frac{A_{d} E_{d}}{l_{o d}}\left[\alpha_{d} \Delta T l_{o d}+\frac{u_{6} A_{l} E_{l} l_{o d}+A_{l} E_{l}\left(\alpha_{l} \Delta T l_{o l} l_{o d}\right)-A_{d} E_{d}\left(\alpha_{d} \Delta T l_{o l} l_{o d}\right)}{\left(A_{l} E_{l} l_{o d}+A_{d} E_{d} l_{o l}\right)}\right]$

Cancelling out the original drum thickness in the equation, the normal force without installation gap will be given as

$F_{l}=A_{d} E_{d}\left[\alpha_{d} \Delta T+\frac{u_{6} A_{l} E_{l}+A_{l} E_{l}\left(\alpha_{l} \Delta T l_{o l}\right)-A_{d} E_{d}\left(\alpha_{d} \Delta T l_{o l}\right)}{\left(A_{l} E_{l} l_{\text {od }}+A_{d} E_{d} l_{\text {ol }}\right)}\right]$

If the installation gap $\left(l_{g)}\right.$ is appeared between the lining and drum then the normal force becomes

$F_{l}=A_{d} E_{d}\left[\alpha_{d} \Delta T+\frac{u_{6} A_{l} E_{l}+A_{l} E_{l}\left(\alpha_{l} \Delta T\left(l_{o l}+l_{g}\right)\right)-A_{d} E_{d}\left(\alpha_{d} \Delta T\left(l_{o l}+l_{g}\right)\right.}{\left(A_{l} E_{l} l_{o d}+A_{d} E_{d}\left(l_{o l}+l_{g}\right)\right.}\right]$

In order to calculate the torque generated at drum brake, $T q_{g e n}$ the radial force at the interface, $F_{f}$ is multiplied by the radius of the drum brake, $r_{d}$

$T q_{g e n}=F_{f} r_{d}$

$T q_{g e n}=\mu_{d} F_{l} r_{d}$

where, $F_{f}=\mu_{d} F_{l}$

Due to design configurations of the drum brake, the applied force at the handbrake lever is different when the vehicle is parked facing uphill or downhill. This can be seen from the forces acting on the brake shoe as depicted in Figures 6a and $6 \mathrm{~b}$.
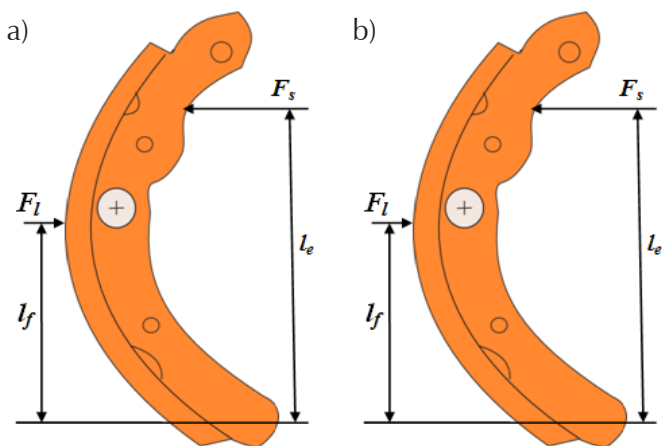

Figure 6 . Forces acting on the brake shoe: a) vehicle facing downhill, b) vehicle facing uphill
From the figures $6 \mathrm{a}$ and $6 \mathrm{~b}$, it can be formulated that the total moment at point 0 is

For vehicle facing downhill $F_{s} l_{e}=F_{l} l_{f}-F_{f} l_{g}$

For vehicle facing uphill $\quad F_{s} l_{e}=F_{l} l_{f}+F_{f} l_{g}$

By substituting Eqs. (1), (2) and (3) into Eqs. (18) and (19), The hand-brake applied force $\mathrm{F}_{\mathrm{hb}}$ can be given as

For vehicle facing downhill $F_{h b}=\frac{F_{l}\left(l_{f}-\mu_{d} l_{g}\right)}{l_{e}}\left(\frac{l_{c}}{l_{d}}\right)$

For vehicle facing uphill

$$
F_{h b}=\frac{F_{l}\left(l_{f}+\mu_{d} l_{g}\right)}{l_{e}}\left(\frac{l_{c}}{l_{d}}\right)
$$

\section{VeHICLE MODEL ON A SLOPE}

Figure 7 shows a vehicle of certain mass $m$ is parked on gradient $\theta$. The weight $(m g)$ of the vehicle is located at the centroid of the vehicle. The weight $(m g)$ of the vehicle acts through its center of gravity (CG). Depending on the incline angle, the weight pulls the vehicle to the ground and pulls it either backward or forward. The weight and the reaction forces are resolved along the road, $x^{\prime}$ direction and perpendicular to the road, $y^{\prime}$ direction. Normal force, $\mathrm{N}$, at each tyre is perpendicular to the road. The frictional force is assumed only at the rear tyre because the parking brake system is attached at the rear wheels. Thus, the force equation in $x^{\prime}$ direction is

$F_{\text {fric }}=\mu_{r} F_{r}=(m g) \sin \vartheta$

As the braking torque of the tyre is equal to the multiplication of frictional force at the tyre and the radius of the wheel, the torque required at the center of the rear wheel to hold the vehicle stationary is

$T q_{\text {req }}=\mu_{r} F_{r} R_{\text {wheel }}=(m g) \sin \vartheta \times R_{\text {wheel }}$

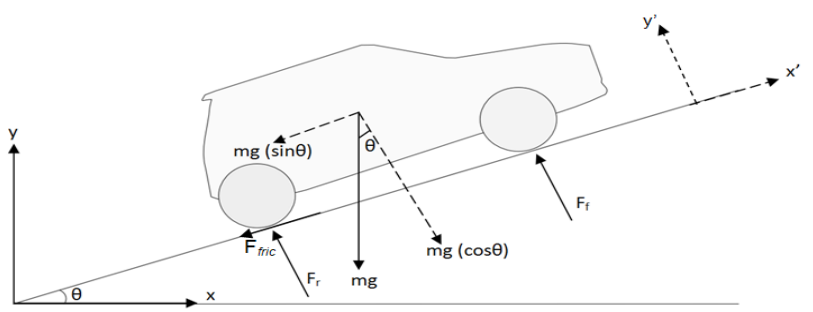

Figure 7. Vehicle on a slope in the uphill direction (Rozaini et al., 2013) 
where

$\mu_{r}=$ friction coefficient between road and tyre,

$F_{r} \quad=$ normal force at the rear tyre and

$R_{\text {wheel }}=$ radius of the tyre.

\section{ResUlts AND DISCUSSION}

In this section, the results are discussed; starting with the verification of the test bench, followed by the prediction of temperature and torque generated by the drum brake. Finally, the parametric study is carried out.

\section{VERIFICATION OF THE TEST BENCH}

Prior to carrying out the experiment on the test bench, the test bench must closely behave as the actual parking brake performance. This is done by comparing the applied force on the actual hand lever in the vehicle with the dead weight applied on the test bench. The applied forces on both hand-brake levers were based on the number of ratchet teeth the arm went through. The in-vehicle hand-brake force is measured using a spring scale, which is hooked to the handle of the hand-brake and the scale is positioned perpendicular to the lever. The reading was taken once the ratchet pawl slips. In the test bench, deadweight is used to pull the handbrake lever up to $340 \mathrm{~N}$. Figure 8 shows result of the two tests and the results show there is a close correlation between them. This indicates that the test bench can be used in replacing the vehicle test.

\section{Prediction of temperature AND PARKING BRAKE tORQUe}

Predictions of temperature and parking brake torque are made based on Eq. (10) and Eq. (17), respectively. All the parameters and their values used to predict the temperature and torque are given in Table 1. Most of

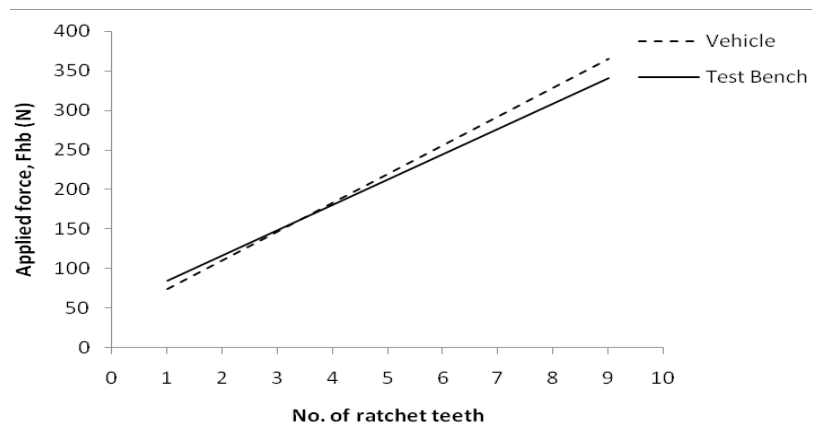

Figure 8. Experimental results of applied force on hand-brake lever the parameters are measured values of the brake components and some of them are taken from other resources as stated in Table 1.

Figure 9a shows that the temperature varies with cooling time after the wheel was run with the brake applied until a temperature of $200^{\circ} \mathrm{C}$ was reached. It is seen that a quick temperature drop occurs at the start of cooling time before 500s and then, the temperature drop is more gradual. It is also observed that there is no significant difference in the cooling temperature curve for all cases of hand-brake applied forces. In addition, similar temperature curves are also predicted for the downhill and uphill direction. These prediction results are almost identical to the results obtained in the experiment as shown in Figure 9b. From the cooling temperature curve, the normal force in Eq. (16) can be calculated and later, the parking brake torque can also be predicted. From the experiment, it is found that $u_{6}$ in Eq. (16b) can be represented by

$u_{6}=3.89 \times 10^{-7 *} \mathrm{Fhb}-1.5 \times 10^{-5}$

Having known the relationship of temperature change and cooling time, the torque generated by the parking brake can be obtained for various hand-brake applied forces. Figure 10 depicts parking brake torque curves calculated from Eq. (17) in the downhill direction and it can be seen that a good correlation is achieved against measured data. From this correlation, parking brake torque for $\mathrm{F}_{\mathrm{hb}} \mathrm{C}=400 \mathrm{~N}$ can be predicted using the same equation. A good correlation is also achieved for the uphill direction as plotted in Figure 11. From these two plots, it shows that the parking brake torque generated is much higher in the downhill direction than the uphill direction with the same applied force of $\mathrm{F}_{\mathrm{hb}}=400 \mathrm{~N}$. This is due to the design of the drum brake leading-trailing shoe mechanism (Limpert, 1999) and is also supported by Eqs. (20) and (21). The significant observation in the results as shown in Figure 10 and Figure 11 is that the drum brake torque is not very much affected by temperature variations of the brake. This is differed with the finding of McKinlay et al. (2004) for the disc brake. The reason can be due to the curved shape of the brake shoes and drum compared to the flat shape of the brake pads and disc. The brake pad can easily be detached from the disc surface during the cooling process. Another possible reason is that the normal brake pad movement is much smaller compared to the brake shoes, thus would have a larger ratio of disengagement when the disc cools off. For these two reasons, the clamping force and brake torque will be reduced significantly. 
DOI: http://dx.doi.org/10.22201/fi.25940732e.2018.19n1.004

BRAKE TORQUE ANALYSIS OF FULly MECHANICAL PARKING BRAKE SYSTEM: THEORETICAL AND EXPERIMENTAL APPROACH

Table 1. Parameters and values used in the parking brake model

\begin{tabular}{|c|c|c|c|c|c|}
\hline Parameters & Value & Unit & Parameters & Value & Unit \\
\hline $\begin{array}{l}\text { Ambient Temperature, } \\
T_{a m b}\end{array}$ & 27 & ${ }^{\circ} \mathrm{C}$ & Modulus Young of lining, $E_{l}$ & $\begin{array}{c}2.1 \times 10^{8} \text { (Wolff et } \\
\text { al., 2010) }\end{array}$ & $\mathrm{Nm}^{-2}$ \\
\hline Mass of vehicle, $m$ & 1250 & $\mathrm{~kg}$ & Surface area of drum, $A_{d}$ & $2.2 \times 10^{-3}$ & $\mathrm{~m}^{2}$ \\
\hline Mass of driver, $m_{d}$ & 70 & $\mathrm{~kg}$ & Surface area of lining, $A_{l}$ & $4.8 \times 10^{-3}$ & $\mathrm{~m}^{2}$ \\
\hline Volume of drum, $V$ & $7.7 \times 10^{-4}$ & $\mathrm{~m}^{3}$ & $\begin{array}{l}\text { Thermal expansion coefficient of } \\
\text { drum, } \alpha_{d}\end{array}$ & $\begin{array}{c}1.1 \times 10^{-5} \\
\text { (Limpert,1999) }\end{array}$ & ${ }^{\circ} \mathrm{C}^{-1}$ \\
\hline Radius of drum, $r_{d}$ & 0.09 & $\mathrm{~m}$ & $\begin{array}{l}\text { Thermal expansion coefficient of } \\
\text { lining, } \alpha_{l}\end{array}$ & $\begin{array}{l}1.2 \times 10^{-5}(\text { see } \\
\text { ref,1998) }\end{array}$ & ${ }^{\circ} \mathrm{C}^{-1}$ \\
\hline $\begin{array}{l}\text { Specific heat capacity of } \\
\text { drum, } c_{p}\end{array}$ & 586 ( see.ref,1998) & $\underset{{ }^{\circ} \mathrm{C}^{-1}}{\mathrm{~kg}^{-1}}$ & Drum thickness, $l_{o d}$ & 0.008 & $\mathrm{~m}$ \\
\hline Density of drum, $\rho$ & $\begin{array}{l}7100 \text { (Day et } \\
\text { al.,1984) }\end{array}$ & $\mathrm{kg} \mathrm{m}^{-3}$ & Lining thickness, $l_{o l}$ & 0.004 & $\mathrm{~m}$ \\
\hline Radius of wheel, $R_{\text {wheel }}$ & 0.3 & $\mathrm{~m}$ & Friction coefficient (shoes/drum) & $0.3 \sim 0.6$ & \\
\hline $\begin{array}{l}\text { Modulus Young of } \\
\text { drum, } E_{d}\end{array}$ & $\begin{array}{c}1.1 \times 10^{11}(\text { Wolff et } \\
\text { al. }, 2010)\end{array}$ & $\mathrm{Nm}^{-2}$ & Initial gap between lining and drum & 1 & $\mathrm{~mm}$ \\
\hline
\end{tabular}

a) Calculated

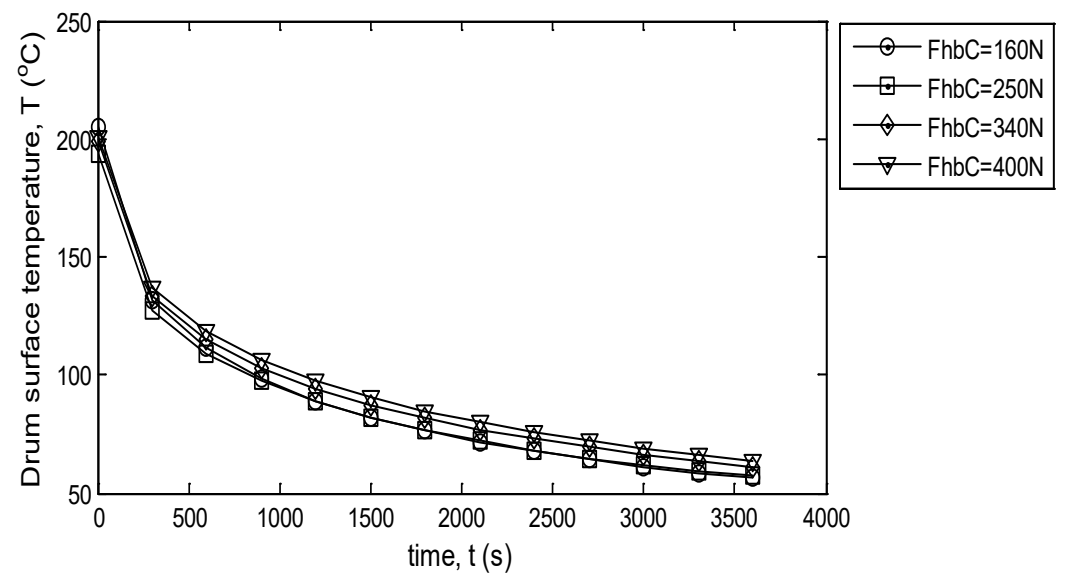

a) Measured

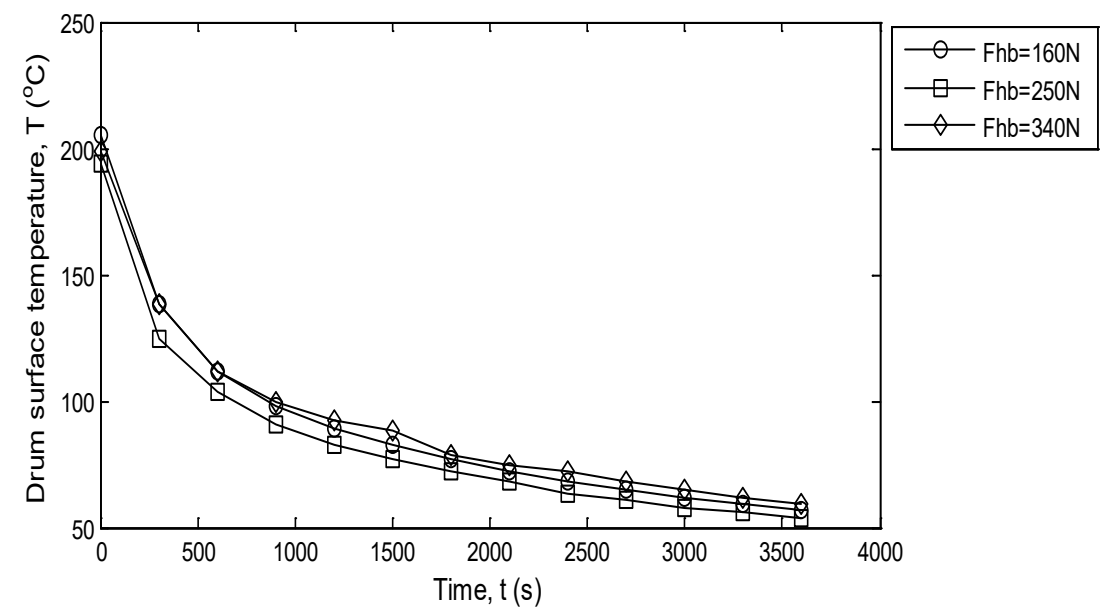

Figure 9. Brake temperatures being cooled over time 

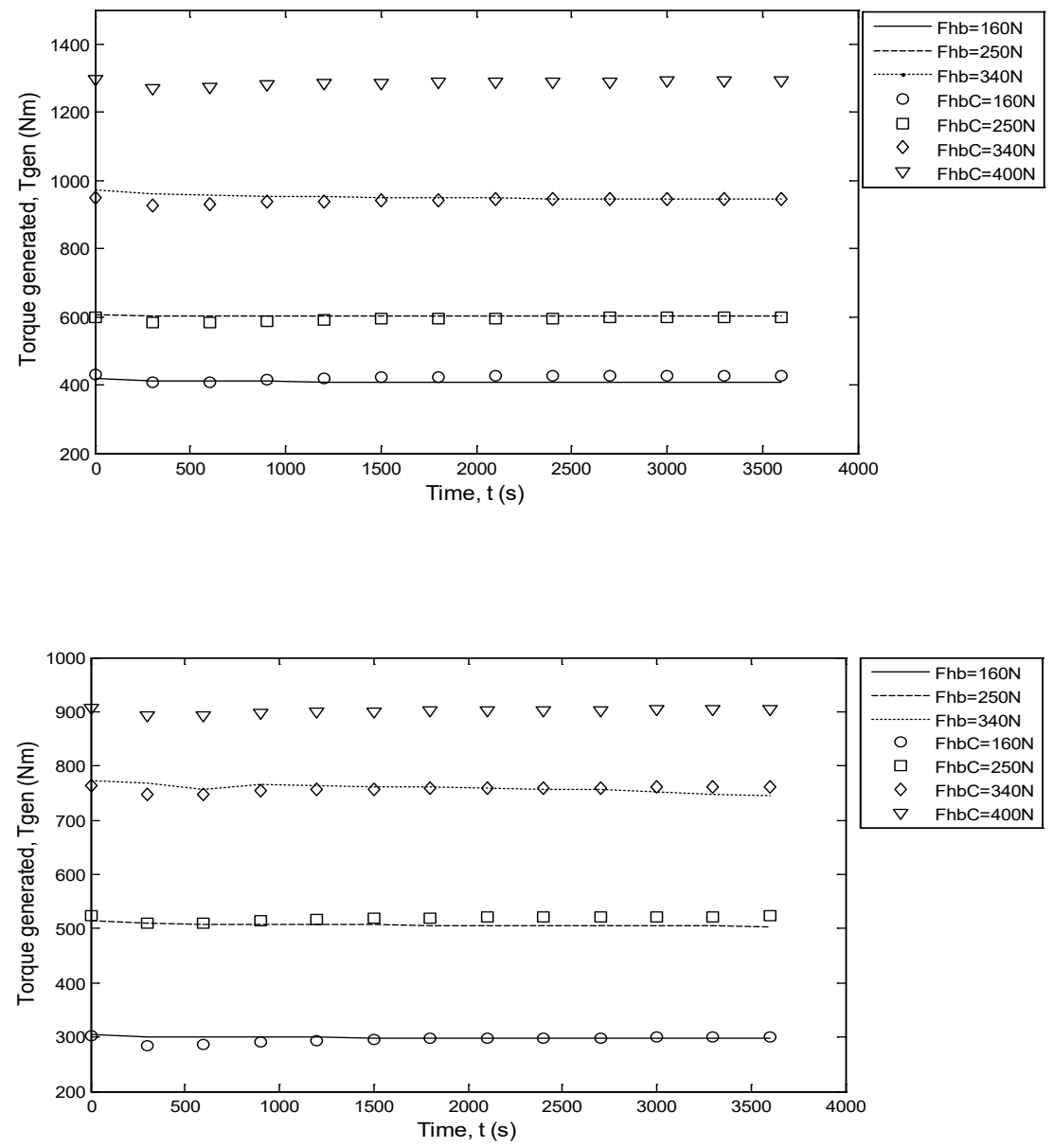

Figure 10. Parking brake torque for vehicle facing downhill (Fhb $=$ measured, $\mathrm{FhbC}=$ calculated $)$
Figure 11. Parking brake torque for vehicle facing uphill (Fhb=measured, FhbC $=$ calculated)
According to FMVSS 135 (U.S. National Highway, 2005), a vehicle weighing $3500 \mathrm{~kg}$ and below should be able to remain stationary on $20 \%$ or $11.3^{\circ}$ grade roads for 5 minutes in both forward and reverse direction when $400 \mathrm{~N}$ or less force is applied at the hand control mechanism. From Figure 12, the torque generated by the parking brake in the downhill and uphill direction at $\mathrm{F}_{\mathrm{hb}}=400 \mathrm{~N}$ is much higher than the torque required for a slope of $11.3^{\circ}$. This indicates that the current parking brake design that is used in this work complies with FMVSS 135 regulation.

\section{Parametric studies}

After the parking brake model is validated, the model can be used to predict brake torque performance due to changes in some of the parameters of the brake components and the vehicle. They are the drum/lining coefficient of friction and the vehicle weight. The effect of the installation gap between the shoes and the drum is not considered because the motivation of this work is to investigate thermal effect which is required the shoes always in contact with the drum. To ensure a vehicle in a stationary state, the torque generated by the parking brake must always be higher than the torque required for certain road slope (Tgen $>$ Treq). This is shown in Figure 13 that the vehicle is in a stationary condition on the slanting road when the friction coefficient between drum and lining is above 0.2 .

Figure 14a and Figure 14b show the brake torque performance with various vehicle weights in the downhill and uphill direction, respectively. As stated in Table 1 , the weight of the vehicle is $1250 \mathrm{~kg}$ and the passenger weight is assumed to be $70 \mathrm{~kg}$ per person. It shows that the vehicle will not roll away in the uphill and downhill direction, even though there are five passengers inside the vehicle. This is because the torque generated by the parking brake is much higher than the torque required with five passengers. 
DOI: http://dx.doi.org/10.22201/fi.25940732e.2018.19n1.004

BRAKE TORQUE ANALYSIS OF FULly MECHANICAL PARKING BRAKE SYSTEM: THEORETICAL AND EXPERIMENTAL APPROACH

a) Downhill

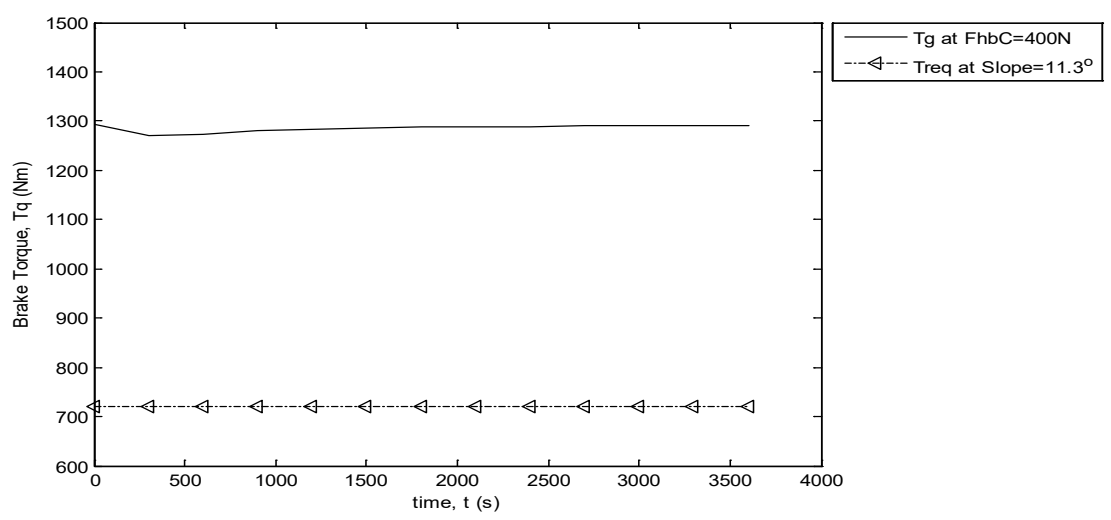

b) Uphill
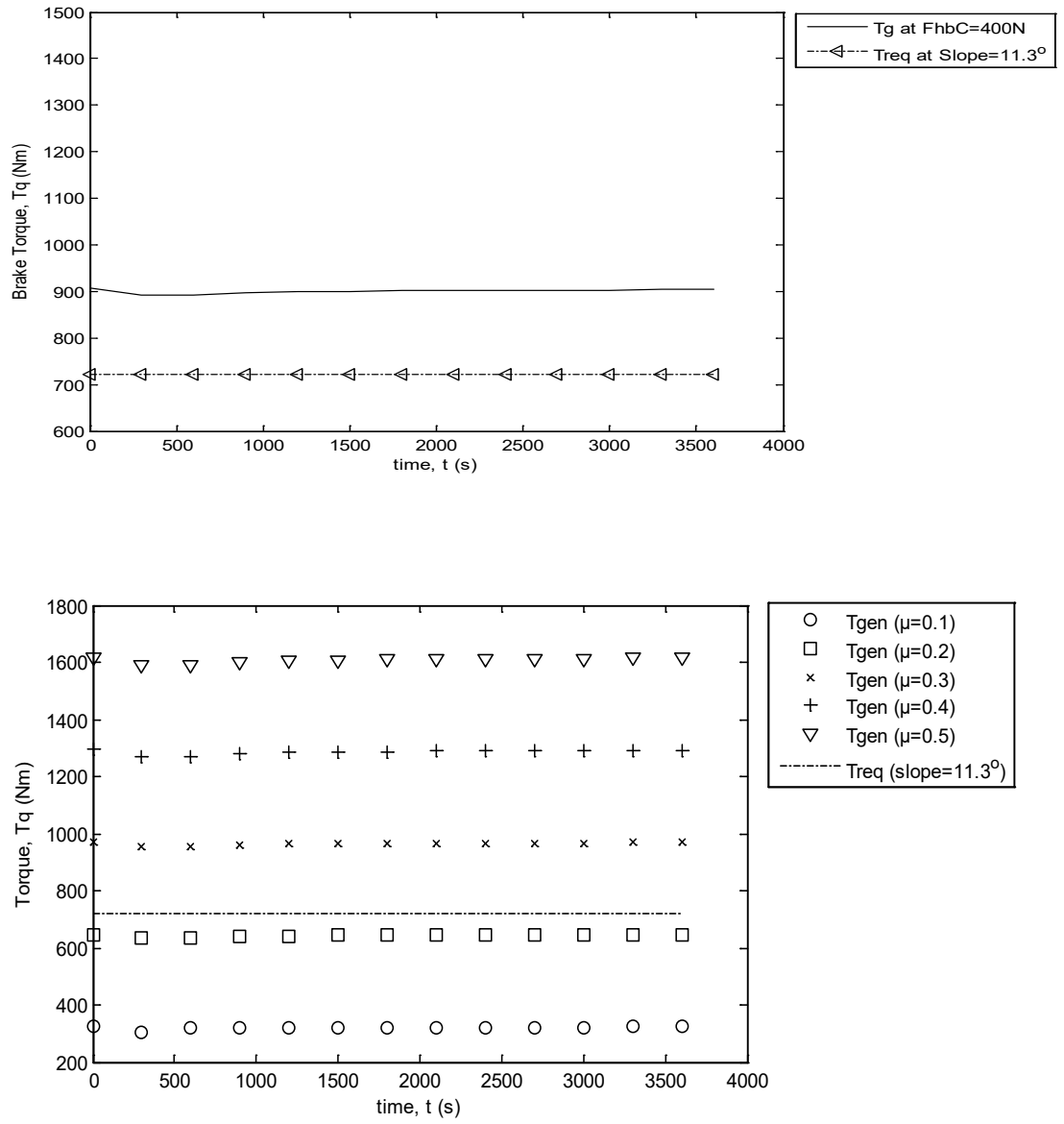

Figure 12. Calculated parking brake torque performance

Figure. 13. Brake torque performance for different friction coefficients 

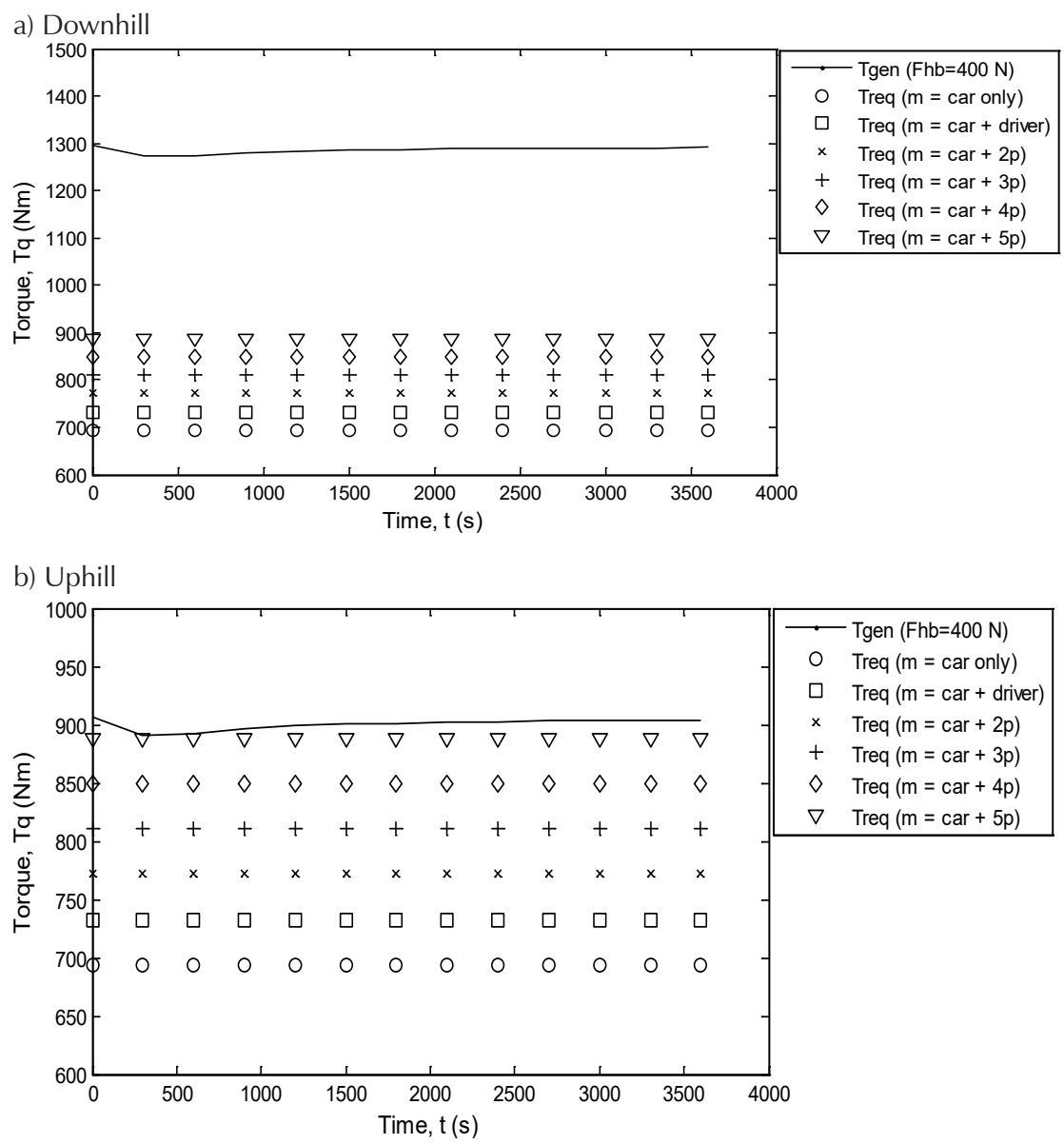

Figure. 14. Brake torque performance in various vehicle weights

\section{ConCLUSION}

This paper attempts to find the validated parking brake model in order to predict its torque performance with the aim to avoid vehicle roll away phenomena from the parked condition. In doing so, parking brake test bench was firstly developed with the intention to validate the parking brake model. To ensure the validity of the bench, a comparison was made against vehicle test data and a better agreement was demonstrated between them. Then, one dimensional parking brake model with consideration of the temperature effect is proposed. A good correlation of temperature change and parking brake torque between the model and the test bench was also demonstrated. In addition, the parking brake unit used in this work was identified as comply with the FMVSS 135 regulation. The result also shows that the torque generated by the parking brake in the downhill direction is much higher than in the uphill direction. This is due to the leading-trailing shoe type used in the drum brake mechanism. It is observed that the drum brake torque is not very much affected by temperature reduction. Thus, temperature effect on the drum parking brake is not an issue for vehicle roll away. From the parametric studies, it is seen that the vehicle will not roll away when the friction coefficient of the brake lining is above 0.2 and that the parking brake can hold the vehicle stationary with five occupants inside it.

\section{ACKNOWLEDGEMENTS}

The authors would like to thank the Ministry of Science, Technology and Innovation Malaysia (MOSTI) and Universiti Teknologi Malaysia (UTM) for their continuous support in the research work. This research was fully supported by a research grant (Research University Grant Vot. 79390).

\section{REFERENCES}

Aleksendric' D. and Barton D.C. Neural network prediction of disc brake performance. Tribology International, volume 42, 2009: 1074-1080. 
Bao J., Zhu Z., Tong M., Yin Y., Peng Y. Influence of braking pressure on tribological performance of non-asbestos brake shoe for mine hoister during emergency braking. Industrial Lubrication and Tribology, volume 64 (issue 4), 2012: 230-236.

Belhocine A. and Bouchetara M. Simulation of fully coupled thermomechanical analysis of automotive brake discs. Simulation, volume 88 (issue 8), 2012: 921-935.

Bortoni-Anzures L., Gómez-Meléndez D., Herrera-Ruíz G. Martínez-Madrid M. Fuzzy controller for automatic steering in heavy vehicle semi-trailers. Ingeniería Investigación y Tecnología, volume XIV (issue 1), January-March 2013: 1-9.

Carrillo-González J.G., Arámburo-Lizárraga J., Ortega-Magaña R. Modeling the turning speed and car following behaviors of autonomous vehicles in a virtual world. Ingeniería Investigación y Tecnología, volume XVI (issue 3), July-September, 2015: 391-405.

Day A.J., Harding P.R.J., Newcomb T.P. Combined thermal and mechanical analysis of drum brakes. Journal of Automobile Engineering, (issue 198D), 1984: 287-294.

Huang J., Krousgrill C.M., Bajaj A.K. Modeling of automotive drum brakes for squeal and parameter sensitivity analysis. Journal of Sound and Vibratio, volume 289 (issues 1-2), 2004: 245-263.

Hwang P., Wu X., Jeon Y.B. Thermal-mechanical coupled simulation of a solid brake disc in repeated braking cycles. Journal of Engineering Tribology, volume 223, 2009: 1041.

Koylu H. and Cinar A. Experimental design of control strategy based on brake pressure changes on wet and slippery surfaces of rough road for variable damper setting during braking with activated anti-lock brake system. Journal Automobile Engineering, volume 226 (issue 10), 2012: 1303-1324.

Limpert R. Brake design and safety, $2^{\text {nd }}$ ed., Warrendale, Pa: Society of Automotive Engineers, Inc., 1999.

McKinlay A.J., Brooks P.C., Pindar D., Bissett A. The mystery of vehicle roll away. Braking 2004: Vehicle Braking and Chassis Control, Leeds, United Kingdoms, IMechE, 2004, pp. 283-294.
McKinlay A.J., Brooks P.C., Barton D.C. A Study of vehicle handbrake roll away: Thereotical, numerical and experimental assessment. Vehicle Braking Technology. 2006, York, England, IMechE, 2006, pp. 3-12.

Mutlu I., Eldogan O., Findik F. Production of ceramic additive automotive brake lining and investigation of its braking characterisation. Industrial Lubrication and Tribology, volume 57 (issue 2), 2005: 84-92.

Rozaini A.H., Ishak M.R., Abu-Bakar A.R., Mohd-Zain M.Z. Performance of a fully mechanical parking brake system for passenger cars. IOP Conf. Series: Materials Science and Engineering, volume 50, 2013: 1-8.

Tao J.J. and Chang H.T. A System approach to the drag performance of disc brake caliper, $21^{\text {st }}$ Annual Brake Colloquium and Exhibition, October 6-8, 2003, Hollywood, Florida USA, SAE International, 2003.

Tirovic M., Sergent N., Campbell J., Roberts P., Vignjevic R. Structural analysis of a commercial vehicle disc brake caliper. Journal of Automobile Engineering, (issue 226), 2011: 613.

Thiessen F.J. Automotive braking systems, Englewood Cliffs, Prentice-Hall, 1987.

U.N. Inland Transport Division. UNECE Regulations, United Nations, R13-H, 2008.

U.S. National Highway Traffic Safety Administration. Hydraulic and electric brake systems, United State, FMV105, 1998.

U.S. National Highway Traffic Safety Administration. Light vehicle brake systems, United State, 2005.

Wolff A. A Method to achieve comparable thermal states of car brakes during braking on the road and on a high-speed rollstand. The archives of transport, (issue 22), 2010: 111.

Xiaoyan Z., Peixin Q., Xiaojing L. Braking performance study for automobile with numerical simulation. Applied mechanics and materials, volume 155-156 (issue 2012), 2012: 1159-1163.

Zhang Z., Chen J., Bofu W. The control strategy of optimal brake energy recovery for a parallel hydraulic hybrid vehicle. Journal of Automobile Engineering, volume 226 (issue 11), 2012: 1445-1453. 


\section{Suggested citation:}

\section{Chicago style citation}

Mohd-Razmi, Ishak, Abu Bakar Abd-Rahim, Belhocine Ali, Taib Jamaludin-Mohd, Wan Omar Wan-Zaidi. Brake torque analysis of fully mechanical parking brake system: Theoretical and experimental approach. Ingeniería Investigación y Tecnología, XIX, 01 (2018): 37-49.

\section{ISO 690 citation style}

Mohd-Razmi I., Abd-Rahim A.B., Belhocine A., Jamaludin-Mohd T., Wan-Zaidi W.O. Brake torque analysis of fully mechanical parking brake system: Theoretical and experimental approach. Ingeniería Investigación y Tecnología, volume XIX (issue 1), January-March 2018: 37-49.

\section{AвOUt the AUthors}

Ishak Mohd-Razmi. Is currently A Senior Lecturer at Aeronautical, Automotive and Offshore Engineering Department, Faculty of Mechanical Engineering, Universiti Teknologi Malaysia, UTM 81310 Johor Bahru, Johor, Malaysia.

Abu Bakar Abd-Rahim. Is currently A Senior Lecturer at Aeronautical, Automotive and Offshore Engineering Department, Faculty of Mechanical Engineering, Universiti Teknologi Malaysia, UTM 81310 Johor Bahru, Johor, Malaysia.

Ali Belhocine. Received his Magister degree in Mechanical Engineering in 2006 from Mascara University, Mascara, Algeria. He has recently obtained his Ph.D degrees in Mechanical Engineering at the University of Science and the Technology of Oran (USTO Oran, Algeria) in 2012. His research interests include Automotive Braking Systems, Finite Element Method (FEM), ANSYS simulation, CFD Analysis, Heat Transfer, Thermal-Structural Analysis, Tribology and Contact Mechanic.

Taib Jamaludin-Mohd. Is currently a Senior Lecturer at Aeronautical, Automotive and Offshore Engineering Department, Faculty of Mechanical Engineering, Universiti Teknologi Malaysia,UTM 81310 Johor Bahru, Johor, Malaysia.

Omar Wan-Zaidi Wan. Is currently A Senior Lecturer at Aeronautical, Automotive and Offshore Engineering Department, Faculty of Mechanical Engineering, Universiti Teknologi Malaysia, UTM 81310 Johor Bahru, Johor, Malaysia. 